\title{
Differences in the perception of corporate culture as a motivational tool in the SME sector
}

\author{
Iveta $\mathrm{Kmecova}^{1, *}$, and Michal Tlusty ${ }^{2}$ \\ ${ }^{1}$ Institute of Technology \& Business in Ceske Budejovice, Faculty of Corporate Strategy, Department \\ of Human Resource Management, Okruzni 517/10, Ceske Budejovice 37001, Czech Republic \\ ${ }^{2}$ Institute of Technology \& Business in Ceske Budejovice, Okruzni 517/10, Ceske Budejovice 37001, \\ Czech Republic
}

\begin{abstract}
.
Research background: The paper points out the differences in the motivation of employees in SMEs in terms of corporate culture as a motivational tool. The primary goal of the paper is to draw conclusions from hypotheses that analyse corporate culture as a motivational tool. Literary research outlines the issue of personnel activities focusing on the corporate culture as a motivational tool for SMEs in the Czech Republic. The practical part of the paper shows the whole course of specific calculations and evaluation of established hypotheses. At the end of the solution of each hypothesis, its rejection or confirmation is displayed, and this is justified by other methods that confirm this decision.

Purpose of the article: The main purpose of the article is to confirm or reject predetermined hypotheses concerning small and medium-sized enterprises. A specific evaluation of the hypotheses will help to raise the profile of possible problems of small and medium-sized enterprises in the areas of employee motivation.

Methods: Primary data for this article were obtained using an online questionnaire. The data are evaluated using a statistical method comparing the mean values of the samples, specifically using a statistical one-sample test. The research sample consisted of a total of 220 small and medium-sized enterprises (SMEs) in the Czech Republic.

Findings \& Value added: The results of the research will confirm or not confirm whether corporate culture is an important motivating tool for small and medium-sized enterprises and whether or not it differs depending on the division of enterprises according to different scales.
\end{abstract}

Keywords: work motivation; one-sample t-test; SME; corporate culture; non-financial motivational tool

JEL Classification: $M 12$

\footnotetext{
* Corresponding author: kmecova@mail.vstecb.cz
} 


\section{Introduction}

Motivated employees are a highly important factor relating to human resources in all successful domestic of foreign companies, being a cornerstone of a profitable enterprise.

Multiple companies consider a human factor as a way to success and risk reduction, seeking a working environment which maximizes performance and minimizes losses [1]. Corporations achieve goals through their employees, which involves exploring their positive and negative sides with the view to strengthening their motivation to perform well. Motivational factors play a pivotal role to adopt an effective strategy to enhance the performance of the working team, leading to customers' satisfaction [2]. Corporate culture is one of these motivational tools. Having approved of the corporate culture and decisions, the employee feels better, steadily performing on a high level $[3,4,5]$.

The article concerned focuses on differences in motivating employees in small and medium-sized enterprises regarding the corporate culture as a motivational tool.

\section{Theoretical background}

Determining appropriate elements of non-financial motivation is a fundamental task for a smooth running of the enterprise. While employees' motivation comprised mostly financial components in the last century, with the new century coming workers more and more appreciate non-monetary motivational tools. A comprehensive study analysed whether it is possible to better understand motivational profiles of individual employees in an enterprise to strengthen their motivation in the workplace. The research suggested five motivational profiles, which were: 1) inner motivation, 2) poor motivation, 3) external motivation, and 4) self-motivation [6], formulating the hypothesis as follows: financial motivational tools do not influence the working performance of employees. The research included a sample of restaurant businesses, analysing their profit rate after workers' salary and wage increases. The results suggest the confirmation of the hypothesis, indicating the restaurants' profit rate did not improve despite the increase in costs of salaries and wages. In the event of a separate salary rise, e.g. promotion or good job, the results show a productivity improvement on the short-term scale although falling back to average values on the long-term basis [7]. Another analysis focused on examining the influence of unhealthy working environment exerted by a boss on the motivation of subordinate employees in the academic environment and its ethical consequences. The author concluded that although workers in the unfavourable and unethical environment cannot do other but withstand the pressure, this behaviour deeply affects their energy levels, resulting in demoralized stimuli which may lead to giving notice or taking revenge on the superior [8]. Another study reflected upon whether corporate structures influence the motivation of employees. The results show that a wrongly established organizational structure or poor leadership considerably affect the motivation of senior workers, causing them problems which significantly influence their performance [9]. Other important motivational factors include training courses dealt with in a study exploring educational influences and training employees on their work motivation. The findings suggested that training and education have only a slight influence on motivation and productivity of inferiors or, even regarding them as annoying and useless. Senior workers indicated contrary values, showing interest in training courses and further education, younger senior employees in particular [10]. Different research concerned with training courses and education, analysing the influence of training on the motivation of workers in the hospital environment. Authors divided hospital employees into four groups (managers, nurses, rehabilitation specialists and hospital employees). The results indicated that training courses have the greatest impact on the motivation of managers, followed by rehabilitation specialists, then hospital workers and nurses in the last position [11]. The analysis continues 
with examining Industry 4.0. The research tackled experts in the area of human resource management, suggesting that the respective professionals consider their career growth and remuneration as the strongest motivation [12]. Other studies propose that also age and sex play an important role in motivation, exploring generation differences in perceiving motives in the workplace. Three groups included employees according to age named generation $X, Y$ and $\mathrm{Z}$; $\mathrm{X}$ group involving the youngest, while $\mathrm{Z}$ comprising the oldest workers. $\mathrm{Y}$ group constituted average-age employees. $Y$ generation showed the highest motivation in the workplace, i.e. average-age workers, the reason being to support the family in its early phases [13]. Another study examined the influence of sex on motivating senior employees. The findings indicated that men and women consider different motivation stimuli. Women prefer a steady job and a friendly environment, whereas men pursue high salary and career growth $[14,15]$.

The suggested data show that the motivation of workers changed through the years; before, employees preferred financial stimuli such as bonuses etc. while today indicates contrary trends when people have come to realize that 'money is not everything', prioritizing non-financial motivation enhancing their long-term performance and creating a friendlier environment. Employees know that despite big salaries, they are unhappy with their jobs when the working atmosphere is hostile and stifling, resulting in personal and overall underperformance of the company.

\section{Methods and Data}

The main purpose of the article is to confirm or reject predetermined hypotheses concerning small and medium-sized enterprises. A specific evaluation of the hypotheses will help to highlight the possible problems of small and medium-sized enterprises in the area of employee motivation. Companies rated corporate culture on a scale of points 1-4.

\subsection{The methods of data collection}

The research sample of companies was divided according to three criteria. The first criterion concerned the motivation of employees in the company, specific dividers were a measure of whether companies evaluate the motivation of their employees as appropriate or, conversely, inappropriate for the needs of a particular company. The second scale divided the sample according to the sector in which the company operates. One part was a joint group of companies operating in the primary and secondary sectors. The second part included companies that do business in the tertiary sector. The last division concerned employee training. One part was made up of companies that consider training to be an important tool for a company's competitiveness. The second part included companies that, on the other hand, do not consider employee training to be an important aspect of their company's competitiveness.

\subsection{The methods of data assessment}

The use of statistical methods was chosen to analyse the above variables. Specifically, it is a comparison of data using a one-sample t-test, supplemented by critical values, evaluation according to $\mathrm{p}$-values and comparison of $95 \%$ quartiles of values [16]. For this calculation, it is necessary to calculate the relevant quantities, namely the arithmetic mean, the sample variance, the standard and standard deviation. When these quantities are known, it is possible to calculate a specific t-test value Furthermore, it is necessary to establish null hypotheses 
and relevant alternative hypotheses. In the next step, the one-sample t-test itself can be calculated. The $95 \%$ confidence interval was chosen for this post [17].

Where:

$$
t=\frac{\bar{x}-\mu_{0}}{\sigma} \sqrt{n}
$$

$t=$ value of one-sample t-test

$\bar{x}=$ arithmetic mean

$\mu_{0}=$ established null hypothesis

$\sigma=$ standard deviation

$n=$ number of sample values

Finally, it is necessary to compare the calculated values of the one-sample t-test with the critical values from the tables that are available on the Internet. If the final value of the t-test is lower than the critical value, the hypothesis can be confirmed. Otherwise, if the calculated t-test value is higher than the corresponding critical value, the hypothesis is rejected [18].

\section{Results}

Null hypothesis: Companies that evaluate the motivation of their employees as corresponding to the needs of the company, find the corporate culture (motivational tool) important by 3.2 point. Companies that evaluate the motivation of their employees as not corresponding to the current needs of the company find corporate culture (motivational tool) important by 3.2 point. (comparation)

$$
\begin{aligned}
& t_{1}= \frac{3.29-3.2}{0.77} \sqrt{129}=1.33 \\
& t_{2}= \frac{3.12-3.2}{0.88} \sqrt{91}=-0.87 \\
& \quad \text { critical value }_{1}=-1.96 ; 1.96 \\
& \text { critical value }_{2}=-1.987 ; 1.987
\end{aligned}
$$

Both resulting t-test values are smaller than the respective critical values and so it is possible to confirm the whole hypothesis. These statements can also be confirmed using pvalues obtained using the R-commander statistical software.

$$
\begin{aligned}
& p-\text { value }_{1}=0.2041=20.41 \% \\
& p-\text { value }_{2}=0.3933=39.33 \%
\end{aligned}
$$

As mentioned in the methodological part, t-tests took place at a level of significance of $95 \%$ and so it is necessary to compare the resulting $\mathrm{p}$-values with a value of $5 \%$. $\mathrm{P}$ - the value of the first selection is $20.41 \%$. This value is higher than $5 \%$, so this method also confirms the hypothesis. The second p-value is $39.33 \%$ and again, this value is also higher than $5 \%$ and so the confirmation of the second part of the hypothesis is proved in this way. These statements are confirmed by $95 \%$ of the sample quartile. The $95 \%$ quartile for the first selection is 3.15 to 3.42 and the value of the null hypothesis was 3.2 , which falls into this quartile. The second $95 \%$ quartile corresponds to values of 2.94 to 3.3 and the value of 3.2 therefore falls within this range.

Null hypothesis: Companies operating in the primary and secondary sectors find corporate culture (motivational tool) important by 3.2 point. Companies operating in the tertiary sector find corporate culture (motivational tool) important by 3.2 point. (comparation)

$$
\begin{aligned}
t_{1}= & \frac{3.25-3.2}{0.86} \sqrt{97}=0.57 \\
t_{2}= & \frac{3.2-3.2}{0.78} \sqrt{123}=0 \\
& \text { critical value }_{1}=-1.984 ; 1.984
\end{aligned}
$$


critical value $_{2}=-1.96 ; 1.96$

Both final values of t-tests are smaller than their respective critical values and thus the whole hypothesis can be confirmed.

$$
\begin{gathered}
p-\text { value }_{1}=0.5911=59.11 \% \\
p-\text { value }_{2}=1=100 \%
\end{gathered}
$$

The first $p$-value is greater than $5 \%$ and so this method confirms this part of the hypothesis. The second p-value came out $100 \%$, which corresponds to a perfect match and is therefore also confirmed. The $95 \%$ quartile for the first selection is 3.07 to 3.42 . The value of the null hypothesis 3.2 falls within this range. The second $95 \%$ quartile ranges from 3.05 to 3.34 . The value 3.2 can be included in this range, so both parts of the null hypothesis are confirmed in this way.

Null hypothesis: Companies that actively work on training and development of their employees and in the current situation consider these aspects as one of the important tools for competitiveness find corporate culture (motivational tool) important 3.2 point. Companies that do not actively participate in the training and development of their employees and in the current situation for them these aspects do not seem important for their competitiveness find corporate culture (motivational tool) important 3.2 point. (comparation)

$$
\begin{aligned}
& t_{1}=\frac{3.43-3.2}{0.72} \sqrt{129}=3.63 \\
& t_{2}=\frac{2.92-3.2}{0.85} \sqrt{91}=-3.14 \\
& \quad \begin{array}{c}
\text { critical value }_{1}=-1.96 ; 1.96 \\
\text { critical value }
\end{array}=-1.987 ; 1.987
\end{aligned}
$$

The resulting values of the t-tests for this hypothesis are larger than the respective critical values, and thus the whole hypothesis is rejected, with the result that the resulting values are very different. Specifically, it was the importance of 3.43 point versus 2.92 point.

$$
\begin{gathered}
p-\text { value }_{1}=0.0005605=0.05 \% \\
p-\text { value }_{2}=0.002795=0.2 \%
\end{gathered}
$$

Both p-values are less than $5 \%$ and so even in this way both parts of the hypothesis can be rejected. The $95 \%$ quartile for the first selection is 3.3 to 3.56 . The quartile for the second selection is 2.74 to 3.1 . The value of the null hypothesis 3.2 does not fall into any of the quartiles, so this method also confirms the correctness of rejecting the hypothesis.

\section{Discussion of results}

The evaluation of all hypotheses is summarized in Table 1.

Table 1. Summary of the resulting hypotheses.

\begin{tabular}{|c|c|c|c|}
\hline Hypothesis & T-test values & Critical values & Result \\
\hline $\mathrm{H}_{1}$ & $1.33 ;-0.87$ & $\begin{array}{c}-1.987 \text { and } 1.987 ; \\
-1.96 \text { and } 1.96\end{array}$ & Hypothesis confirmed \\
\hline $\mathrm{H}_{2}$ & $0.57 ; 0$ & $\begin{array}{c}-1.987 \text { and } 1.984 ; \\
-1.96 \text { and } 1.96\end{array}$ & Hypothesis confirmed \\
\hline $\mathrm{H}_{3}$ & $3.63 ;-3.14$ & $\begin{array}{c}-1.96 \text { and } 1.96 ; \\
-1.987 \text { and } 1.987\end{array}$ & Hypothesis rejected \\
\hline
\end{tabular}

Source: Own elaboration.

Null hypothesis: Companies that evaluate the motivation of their employees as corresponding to the needs of the company, find the corporate culture (motivational tool) important by 3.2 point. Companies that evaluate the motivation of their employees as not 
corresponding to the current needs of the company find corporate culture (motivational tool) important by 3.2 point. (comparation)

The first hypothesis concerned mainly the motivation of employees in the company. The companies were divided according to whether the motivation of employees is sufficient for the needs of the company or not. Companies divided in this way were subjected to an analysis of whether they found corporate culture (motivational tool) important by 3.2 point. In the first case, it was found that companies that consider their employees sufficiently motivated really consider the corporate culture to be 3.2 point important. The second part of the hypothesis was also confirmed, which examined the same, but for companies, which, on the contrary, stated that their employees are not sufficiently motivated for the needs of the company. The whole hypothesis was therefore confirmed.

Null hypothesis: Companies operating in the primary and secondary sectors find corporate culture (motivational tool) important by 3.2 point. Companies operating in the tertiary sector find corporate culture (motivational tool) important by 3.2 point. (comparation)

For the analysis of the second hypothesis, companies were divided according to the sector in which they operate. The first group consisted of companies operating in the primary or secondary sector. Part of the hypothesis that dealt with this group was confirmed, and it can therefore be argued that companies operating in the primary or secondary sector really consider the importance of corporate culture to be 3.2 point important. The second part of the hypothesis concerned companies operating in the tertiary sector. It was found that this group also considers corporate culture to be 3.2 point important. The whole hypothesis was therefore confirmed.

Null hypothesis: Companies that actively work on training and development of their employees and in the current situation consider these aspects as one of the important tools for competitiveness find corporate culture (motivational tool) important 3.2 point. Companies that do not actively participate in the training and development of their employees and in the current situation for them these aspects do not seem important for their competitiveness find corporate culture (motivational tool) important 3.2 point. (comparation)

To examine the last hypothesis, companies were divided according to whether they actively support the training of employees in the company or do not participate in these activities and do not run or finance collective training. The first part of the hypothesis that companies that are actively involved in employee training find the importance of corporate culture important by 3.2 point has been refuted, as this importance of corporate culture is much higher, about 3.44 point. The second part, which examined the same hypothesis, but the companies in this group did not actively participate in the training of their employees, was also refuted, but in this case, it was because these companies find the corporate culture much less important, about 2.92 point. The whole hypothesis was therefore refuted.

\section{Conclusion}

The acquired data applied the three most compelling criteria which provided other relevant information for further research. We formulated six testable predictions together comprised of three working hypotheses, regarding companies' classification, processing the data by statistical methods, i.e. t-test, p-value analysis and analysis of $95 \%$ quartile importance. The hypotheses examined the influence of three indicators on the corporate culture as a motivational tool. The first pointer was the level of motivation of employees of the enterprise, while the second one classified companies into sectors of operation. The first group concerned with organizations operating in the primary and secondary section, whereas the 
second set included the tertiary division. The last indicator suggested whether corporations actively participate in training their employees. The first statement concerning the motivation of workers confirmed, proposing that both - companies with strongly motivated employees and enterprises with poorly motivated workers consider the corporate culture important by 3.2 point. The second assertion regarding sectoral differences also corroborated, suggesting that organizations perceive the corporate culture consequential by 3.2 point irrespective of the sector. The last hypothesis, exploring the influence of training courses on the corporate culture, did not prove, demonstrating substantial differences. Enterprises actively supporting the training regarded the corporate culture as very important, while companies doing otherwise showed considerably lower values of the importance of the corporate culture.

\section{References}

1. Grecu, V. M., Popescu, I. M., Alben, E., Pacurari, M. N. (2016). Motivation factors for employees - support for operational risk management within an insurance company. In K. S. Soliman (Ed.), Vision 2020: Innovation Management, Development Sustainability, and Competitive Economic Growth: Proceedings of the 28th International Business-Information-Management-Association Conference (pp. 3174-3180). Seville, Spain: IBIMA.

2. Uthappa, M. M., Santosh, K. A. N. (2020). Impact of motivational factors on project team performance. Test Engineering and Management, 83, 5168-5176.

3. Wang, H., Tong, L., Takeuchi, R., and George, G. (2016). Corporate social responsibility: An overview and new research directions. Academy of Management Journal, 59, 534-544.

4. Ližbetinová, L., Hitka, M., Li, C., Caha, Z. (2017). Motivation of employees of transport and logistics companies in the Czech Republic and in a Selected Region of the PRC. MATEC Web of Conferences, 134(2017), 00032.

5. Ližbetinová, L., Hitka, M., and Kleymenov, M. (2018). Motivational preferences of employees in requirements of Czech and Russian transport and logistics enterprises. Nase More, 65, 254-258.

6. Tóth-Király, I., Morin, A. J. S., Bőthe, B., Rigó, A.,Orosz, G. (2020). Toward an Improved Understanding of Work Motivation Profiles. Applied Psychology, forthcoming article.

7. Kim, H. S., Jang, S. (2020). The effect of increasing employee compensation on firm performance: Evidence from the restaurant industry. International Journal of Hospitality Management, 88, UNSP 102513.

8. Baloyi, G. (2020). Toxicity of leadership and its impact on employees: Exploring the dynamics of leadership in an academic setting. HTS Teologiese Studies Theological Studies, 76(2), a5949.

9. Roobol, C. J. J., Koster, F. (2020). How organisations can affect employees' intention to manage enterprise-specific knowledge through informal mentoring: a vignette study. Journal of Knowledge Management, 24(7), 1605-1624.

10. Nguyen, P. V., Tran, T. T. T. (2020). Role of motivation to learn in training transfer and job performance under peer and supervisor support in the Vietnamese public sector. International Journal of advanced and applied sciences 7, 7-18.

11. Gillet, N., Morin, A. J. S., Ndiaye, A., Colombat, P., Fouquereau, E. (2020). A test of work motivation profile similarity across four distinct samples of employees. Journal of Occupational and Organizational Psychology, forthcoming article. 
12. Dhanpat, N., Buthelezi, Z. P., Joe, M. R., Maphela, T. V., Shongwe, N. (2020). Industry 4.0: The role of human resource professionals. SA Journal of Human Resource Management, 18, a1302.

13. Mahmoud, A. B., Fuxman, L., Mohr, I., Reisel, W. D., Grigoriou, N. (2020). "We aren't your reincarnation!" workplace motivation across $\mathrm{X}, \mathrm{Y}$ and $\mathrm{Z}$ generations. International Journal of Manpower, forthcoming article.

14. Fjendbo, T. H. (2020). Leading Employees of Different Genders: The Importance of Gender for the Leadership-Motivation Relationship. Review of Public Personnel Administration, 0734371X20925520, forthcoming article.

15. Bromberg, D. E., Charbonneau, É. (2020). Public Service Motivation, Personality, and the Hiring Decisions of Public Managers: An Experimental Study. Public Personnel Management 49, 193-217.

16. Budíková, M., Králová, M., Maroš, B. (2010). Průvodce základními statistickými metodami [Guide to basic statistical methods]. Praha: Grada.

17. Dalgaard, P. (2008). Introductory Statistics with R. New York: Springer.

18. Sedlačík, M., Neubaeur, J., Kříž, O. (2016). Základy statistiky - Aplikace $v$ technických a ekonomických oborech [Basics of statistics - Applications in technical and economic fields]. Praha: Grada. 